\title{
Synthesis and Structural Characterization of Diene and Benzene Pentaruthenium Clusters $\dagger$
}

\author{
Dario Braga, ${ }^{* a}$ Fabrizia Grepioni, ${ }^{a}$ Piera Sabatino, ${ }^{a}$ Paul J. Dyson, ${ }^{b}$ Brian F. G. Johnson, ${ }^{*, b}$ \\ Jack Lewis, ${ }^{*}, c$ Philip J. Bailey, ${ }^{c}$ Paul R. Raithby ${ }^{c}$ and Dietmar Stalke ${ }^{c}$ \\ a Dipartimento di Chimica 'G. Ciamician', Università di Bologna, via Selmi 2, 40126 Bologna, Italy \\ ${ }^{b}$ Department of Chemistry, The University of Edinburgh, West Mains Road, Edinburgh EH9 3JJ, UK \\ c University Chemical Laboratory, Lensfield Road, Cambridge CB2 1EW, UK
}

\begin{abstract}
Reaction of the square-pyramidal cluster $\left[\mathrm{Ru}_{5} \mathrm{C}(\mathrm{CO})_{15}\right] 1$ with cyclohexa-1,3-diene and $\mathrm{Me}_{3} \mathrm{NO}$ in $\mathrm{CH}_{2} \mathrm{Cl}_{2}$ at ambient temperature affords the novel species $\left[R u_{5} C(C O)_{13}\left(\mu-\eta^{2}: \eta^{2}-C_{6} H_{8}\right)\right] 2$ which has been fully characterized by $X$-ray diffraction studies [monoclinic, space group $P 2, / n, a=16.193(3), b=9.897(2)$, $c=19.536(4) \AA, \beta=98.80(3)^{\circ}$ and $\left.Z=4\right]$. Further reaction of compound 2 with $\mathrm{Me}_{3} \mathrm{NO}$ in the same solvent results in the dehydrogenation of the $\mathrm{C}_{6} \mathrm{H}_{8}$ ligand and the production of two isomers $3 a$ and $3 b$ of the benzene derivative $\left[R u_{5} \mathrm{C}(\mathrm{CO})_{12}\left(\mathrm{C}_{6} \mathrm{H}_{6}\right)\right.$ ]. In agreement with mass spectroscopic and ${ }^{1} \mathrm{H} N M R$ data, the $X$-ray diffraction analysis shows that the benzene ligand is bound in a face-capping mode in $\left[R u_{5} \mathrm{C}(\mathrm{CO})_{12}\left(\mu_{3}-\eta^{2}: \eta^{2}: \eta^{2}-\mathrm{C}_{6} \mathrm{H}_{6}\right)\right]$ 3a and in a terminal mode in $\left[R u_{5} \mathrm{C}(\mathrm{CO})_{12}\left(\eta^{6}-\mathrm{C}_{6} \mathrm{H}_{6}\right)\right] 3 \mathrm{~b}$, respectively. Compound $3 \mathrm{a}$ is triclinic, space group $P 1^{-}, a=9.525(2), b=14.574(3), c=9.484(4) \AA, \alpha=96.29(2)$, $\beta=112.37(3), \gamma=82.33(2)^{\circ}$ and $Z=2 ; \quad 3 b$ is monoclinic, space group $P 2, / c, a=15.26(2)$, $b=16.675(9), c=19.016(9) \AA, \beta=96.04(7)^{\circ}$ and $Z=8$. On heating $3 a$ in hexane a quantitative and irreversible conversion to $3 b$ is observed. Treatment of $3 b$ with carbon monoxide produces the adduct $\left[\mathrm{Ru}_{5} \mathrm{C}(\mathrm{CO})_{13}\left(\eta^{6}-\mathrm{C}_{6} \mathrm{H}_{6}\right)\right]$ aa, which, on the basis of a single crystal $X$-ray diffraction study, has been shown to contain a 'bridged-butterfly' arrangement of five ruthenium atoms. Compound $4 a$ is monoclinic, space group $P 21 / n, a=9.792(4), b=15.718(2), c=16.446(3) \quad \AA, \beta=96.37(2)^{\circ}$ and $Z=4$. On standing in $\mathrm{CH}_{2} \mathrm{Cl}_{2}, 4 a$ undergoes loss of carbon monoxide to give the apical isomer $\left[\mathrm{Ru}_{5} \mathrm{C}(\mathrm{CO})_{12}\left(\mathrm{C}_{6} \mathrm{H}_{6}\right)\right]$ 3c. On heating in hexane over a prolonged period 3c undergoes quantitative isomerization to $\mathbf{3 b}$.
\end{abstract}

In the course of our studies on the synthesis and structure of arene clusters, we have been able to show that benzene readily forms complexes with a wide range of cluster systems. ${ }^{1-6}$ We have reported the synthesis and full structural characterization by single crystal X-ray diffraction studies of a variety of arene derivatives based on $\mathrm{Ru}_{3},{ }^{1} \mathrm{Os}_{3},{ }^{2,3} \mathrm{Os}_{4}{ }^{4}$ or $\mathrm{Ru}_{6} \mathrm{C}$ cluster units. ${ }^{5}$ Formal donation of six electrons from the cyclic system to the cluster orbitals can be achieved either via conventional $\eta^{6}$ bonding, in which the benzene fragment formally replaces a tricarbonyl unit bound to a single metal atom, or via the less common 'face-capping' of a cluster triangular face. In this latter type of bonding extensive localization of single and double bonding is usually observed within the carbon six-membered ring. ${ }^{1,5}$

The isolation of the first arene clusters containing terminal arene ligands, viz. $\left[\mathrm{Ru}_{6} \mathrm{C}(\mathrm{CO})_{14}\left(\eta^{6}\right.\right.$-arene)] (where arene $=$ $\mathrm{C}_{6} \mathrm{H}_{3} \mathrm{Me}_{3}, \mathrm{C}_{6} \mathrm{H}_{4} \mathrm{Me}_{2}$ and $\mathrm{C}_{6} \mathrm{H}_{5} \mathrm{Me}$ ) was reported in $1967 ;^{6}$ the bonding mode was established by an X-ray diffraction study of the mesitylene derivative. ${ }^{7}$ The face-capping bonding mode has been ascertained in the trimetallic species $\left[\mathrm{M}_{3}(\mathrm{CO})_{9}\right.$ $\left.\left(\mu_{3}-\eta^{2}: \eta^{2}: \eta^{2}-C_{6} H_{6}\right)\right]\left(M=R^{1}\right.$ or $\left.\mathrm{Os}^{8}\right)$. These species are of special interest because of the relevance they bear to the chemisorption of benzene on a $\operatorname{Rh}(111)^{9}$ or Os(001) ${ }^{10}$ singlecrystal surface and also, possibly more significantly, because the benzene molecule apparently bonds in a manner more closely resembling that of a triene than a fully delocalized ring system. In this respect the cluster $\left[\mathrm{Ru}_{6} \mathrm{C}(\mathrm{CO})_{11}\left(\eta^{6}-\mathrm{C}_{6} \mathrm{H}_{6}\right)\right.$ $\left.\left(\mu_{3}-\eta^{2}: \eta^{2}: \eta^{2}-C_{6} H_{6}\right)\right]$ is exceptional in that it contains two benzene moieties each bonded in a different manner, viz. one face-capping and one terminal. ${ }^{8}$

† Supplementary data available: see Instructions for Authors, J. Chem. Soc., Dalton Trans., 1993, Issue 1, pp. xxiii-xxviii.
Further studies have revealed that the face-capping benzene in $\left[M_{3}(C O)_{9}\left(\mu_{3}-\eta^{2}: \eta^{2}: \eta^{2}-C_{6} H_{6}\right)\right](M=R u$ or Os $)$ can be displaced to a terminal bonding position on reaction of the cluster with an alkyne. ${ }^{3}$ Thus, it is clear that a systematic and diverse chemistry of arene clusters is emerging which is of relevance not only to the organometallic chemistry of cluster compounds but also to the chemisorption of arenes on the metal surface. Furthermore, the investigation of the crystal structures of some of these carbonyl-arene clusters has afforded insights into the factors controlling the reorientational motion of the arene fragments in the solid state. ${ }^{11}$ We have been able to show that benzene in either co-ordination mode is able to undergo $2 \pi / 6$ reorientational jumping motion in the solid state with relatively low energy barriers at room temperature, while toluene or mesitylene is blocked in its motion by the surrounding ligands and molecules. ${ }^{5}$ It has also been shown that precise relationships exist between the shape of the arene fragments and the molecular self organization within the solid lattice. ${ }^{12}$

In this paper we report a systematic study of the synthesis and structural chemistry of some benzene derivatives of the squarepyramidal carbidocarbonyl cluster $\left[\mathrm{Ru}_{5} \mathrm{C}(\mathrm{CO})_{15}\right] .{ }^{13} \mathrm{~A}$ review on arene cluster chemistry has recently appeared. ${ }^{14}$

\section{Results and Discussion}

The addition of two equivalents of $\mathrm{Me}_{3} \mathrm{NO}$ to $\left[\mathrm{Ru}_{5} \mathrm{C}(\mathrm{CO})_{15}\right] 1$ in dichloromethane in the presence of cyclohexa-1,3-diene produces red $\left[\mathrm{Ru}_{5} \mathrm{C}(\mathrm{CO})_{13}\left(\mathrm{C}_{6} \mathrm{H}_{8}\right)\right] 2$ (Scheme 1), which may be separated in moderate yield after thin-layer chromatography (TLC) on silica using dichloromethane-ethyl acetate-hexane $(2: 1: 17 \mathrm{v} / \mathrm{v})$ as eluent. The molecular formula of 2 was initially established from the mass and ${ }^{1} \mathrm{H}$ NMR spectra. The mass 
Table 1 Spectroscopic data for compounds $2-4^{a}$

\begin{tabular}{|c|c|c|c|c|}
\hline \multicolumn{2}{|c|}{ Compound } & $v(\mathrm{CO})^{a} / \mathrm{cm}^{-1}$ & ${ }^{1} \mathrm{HNMR}^{b}$ & Mass spectrum $m / z^{c}$ \\
\hline 2 & {$\left[\mathrm{Ru}_{5} \mathrm{C}(\mathrm{CO})_{13}\left(\mu-\eta^{2}: \eta^{2}-\mathrm{C}_{6} \mathrm{H}_{8}\right)\right]$} & $\begin{array}{l}2083 \mathrm{~m} \\
2051 \mathrm{~s}\end{array}$ & $\begin{array}{l}5.42(2 \mathrm{H}, \mathrm{m}) \\
4.36(2 \mathrm{H}, \mathrm{m})\end{array}$ & $961(961)$ \\
\hline & & $\begin{array}{l}20015 \\
2032 w(s h)\end{array}$ & $\begin{array}{l}4.30(2 \mathrm{H}, \mathrm{m}) \\
2.74(2 \mathrm{H}, \mathrm{m})\end{array}$ & \\
\hline & & $2020 \mathrm{~s}$ & $1.80(2 \mathrm{H}, \mathrm{m})$ & \\
\hline \multirow[t]{3}{*}{ 3a } & {$\left[\mathrm{Ru}_{5} \mathrm{C}(\mathrm{CO})_{12}\left(\mu_{3}-\eta^{2}: \eta^{2}: \eta^{2}-\mathrm{C}_{6} \mathrm{H}_{6}\right)\right]$} & $2085 \mathrm{~m}$ & $4.12(6 \mathrm{H}, \mathrm{s})$ & $931(931)$ \\
\hline & & $\begin{array}{l}2063 \mathrm{~s} \\
2028 \mathrm{w}(\mathrm{sh})\end{array}$ & & \\
\hline & & $2014 \mathrm{~s}$ & & \\
\hline & & $1890 w(b r)$ & & \\
\hline \multirow[t]{3}{*}{ 3b } & {$\left[\mathrm{Ru}_{5} \mathrm{C}(\mathrm{CO})_{12}\left(\eta^{6}-\mathrm{C}_{6} \mathrm{H}_{6}\right)\right]$} & $2077 \mathrm{~m}$ & $5.93(6 \mathrm{H}, \mathrm{s})$ & $931(931)$ \\
\hline & & $\begin{array}{l}2048 \mathrm{~s} \\
2033 \mathrm{~m}(\mathrm{sh})\end{array}$ & & \\
\hline & & $2010 \mathrm{~s}$ & & \\
\hline \multirow[t]{4}{*}{ 3c } & {$\left[\mathrm{Ru}_{5} \mathrm{C}(\mathrm{CO})_{12}\left(\mathrm{C}_{6} \mathrm{H}_{6}\right)\right]$} & $2078 \mathrm{~m}$ & $5.93(6 \mathrm{H}, \mathrm{s})$ & $931(931)$ \\
\hline & & $2068 \mathrm{~s}$ & & \\
\hline & & $\begin{array}{l}2050 \mathrm{~s} \\
2035 s\end{array}$ & & \\
\hline & & $2011 \mathrm{~s}$ & & \\
\hline \multirow[t]{4}{*}{$\mathbf{4 a}$} & {$\left[\mathrm{Ru}_{5} \mathrm{C}(\mathrm{CO})_{13}\left(\eta^{6}-\mathrm{C}_{6} \mathrm{H}_{6}\right)\right]$} & $2076 \mathrm{~m}$ & $6.36(6 \mathrm{H}, \mathrm{s})$ & $959(959)$ \\
\hline & & $2045 s$ & & \\
\hline & & $2023 \mathrm{~s}$ & & \\
\hline & & $1982 w$ & & \\
\hline
\end{tabular}

${ }^{a}$ Measured in $\mathrm{CH}_{2} \mathrm{Cl}_{2} .{ }^{b}$ Measured in $\mathrm{CDCl}_{3} .{ }^{c}$ Calculated values given in parentheses.

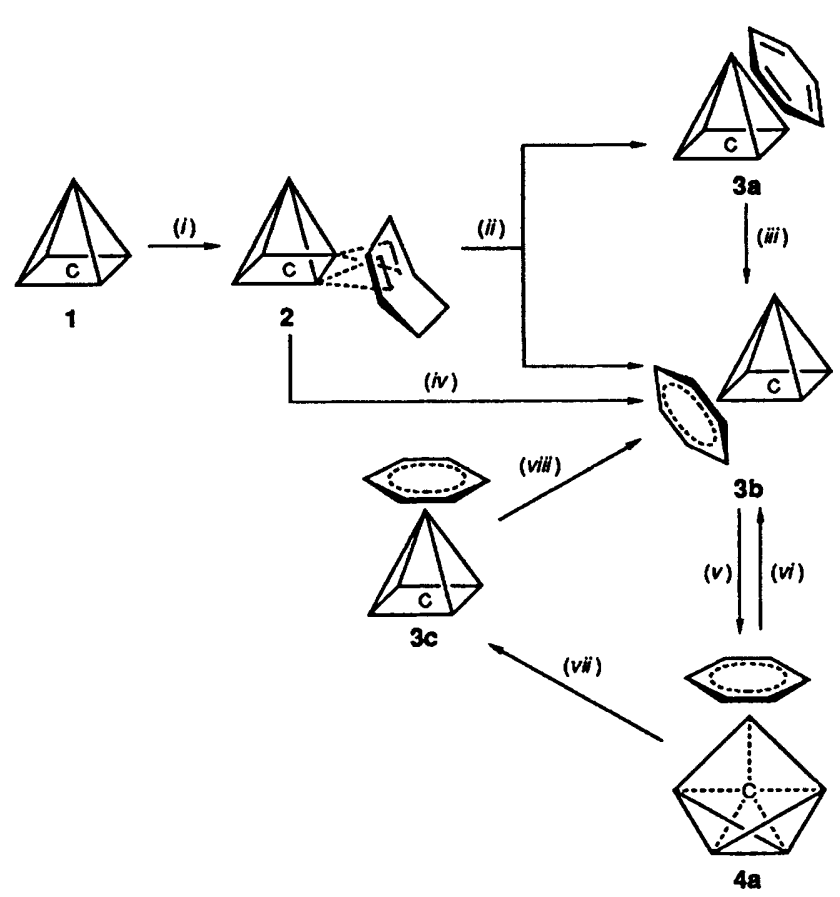

Scheme 1 (i) $\mathrm{Me}_{3} \mathrm{NO}-\mathrm{CH}_{2} \mathrm{Cl}_{2}$ added dropwise to a $\mathrm{CH}_{2} \mathrm{Cl}_{2}$-cyclohexa-1,3-diene solution; (ii) $\mathrm{Me}_{3} \mathrm{NO}-\mathrm{CH}_{2} \mathrm{Cl}_{2}$ added dropwise to a $\mathrm{CH}_{2} \mathrm{Cl}_{2}$ solution; (iii) refluxing hexane for $4 \mathrm{~h}$; (iv) refluxing hexane for $18 \mathrm{~h} ;(v) \mathrm{CO}$ bubbled through a $\mathrm{CH}_{2} \mathrm{Cl}_{2}$ solution; (vi) allowed to stand under $\mathrm{N}_{2}$ immediately after preparation of compound 4 (vii) allowed to stand under $\mathrm{N}_{2}$ after storing compound 4 at $-20^{\circ} \mathrm{C}$ for $24 \mathrm{~h}$; (viii) refluxing hexane for $40 \mathrm{~h}$

spectrum exhibited a strong parent peak together with peaks corresponding to the sequential loss of thirteen $\mathrm{CO}$ groups. The ${ }^{1} \mathrm{H}$ NMR spectrum displayed four multiplets of equal intensity which may be readily assigned to the four different protons of the co-ordinated diene (see Table 1).

The molecular structure of compound $\mathbf{2}$ has been established by single crystal X-ray diffraction and is shown in Fig. 1 together with the atomic labelling scheme. Relevant structural parameters are listed in Table 2 . The metal-atom polyhedron in compound 2 comprises the familiar square-pyramidal frame-

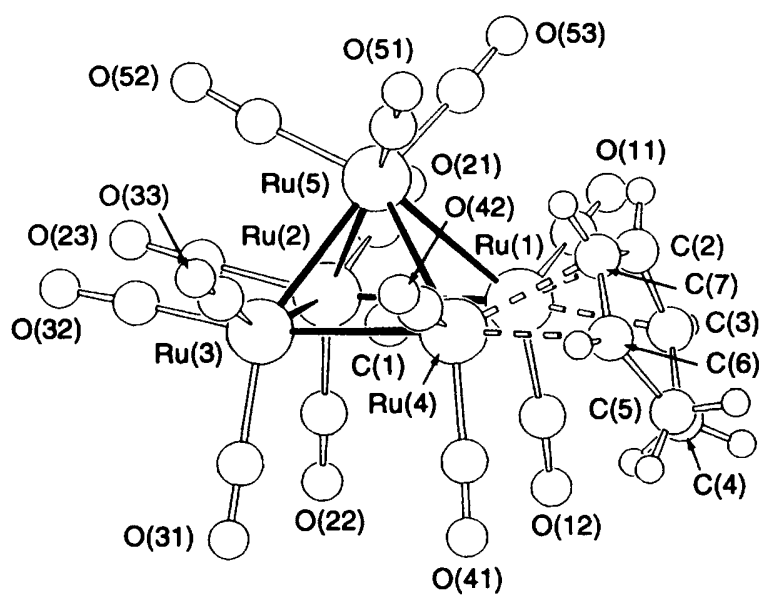

Fig. 1 The solid-state molecular structure of compound 2, showing the atomic labelling scheme; the $\mathrm{C}$ atoms of the $\mathrm{CO}$ groups bear the same numbering as the corresponding $\mathrm{O}$ atoms

work of $\left[\mathrm{Ru}_{5} \mathrm{C}(\mathrm{CO})_{15}\right] .{ }^{13} \mathrm{R}$ uthenium-ruthenium bond lengths range from $2.772(2)$ to $2.909(2) \AA$ [mean $2.831(2) \AA$ ] and are comparable to the values reported for compound 1 [2.800(2)$2.882(2) \AA$, mean $2.840(2) \AA]$. The cyclohexadiene ligand occupies a radial position with respect to the cluster square base. The ligand clearly interacts in $\mu-\eta^{2}: \eta^{2}$ mode with the metal atoms by spanning one basal edge, thus formally replacing one radial $\mathrm{CO}$ on two consecutive $\mathrm{Ru}$ atoms in the parent $\mathrm{Ru}_{5} \mathrm{C}(\mathrm{CO})_{15}$ molecule. The $1,3 \mathrm{C}=\mathrm{C}$ double-bond localization is reflected in the $\mathrm{C}-\mathrm{C}$ distances $[\mathrm{C}(2)-\mathrm{C}(3) 1.39(2)$ and $\mathrm{C}(6)-\mathrm{C}(7) 1.40(2) \AA$ versus an average of $1.46(2) \AA$ for the other $\mathrm{C}-\mathrm{C}$ distances]. In agreement with this bonding pattern the $\mathrm{C}-\mathrm{C}-\mathrm{C}$ angles at the $\mathrm{sp}^{3}$-hybridized carbon atoms are significantly smaller than $120^{\circ}$ [116(1) and $116(1)^{\circ}$ at $\mathrm{C}(5)$ and $\mathrm{C}(4)$, respectively]. The $\mathrm{Ru}-\mathrm{C}($ diene) distances are slightly different, the separation from atoms $C(3)$ and $C(6)$ [mean $2.33(1) \AA]$ being slightly longer than that from atoms $C(7)$ and C(2) [mean $2.28(1) \AA]$.

The formation of compound 2 from the reaction of cyclohexa1,3-diene is not unexpected and is similar to the behaviour 


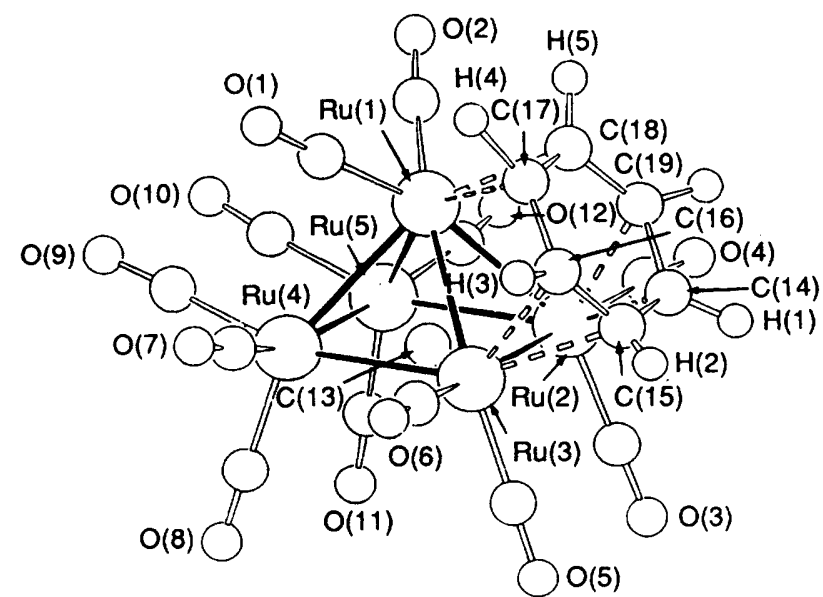

Fig. 2 The solid-state molecular structure of compound 3a, showing the atomic labelling scheme; other detail as in Fig. 1

Table 2 Relevant bond distances $(\AA)$ and angles $\left({ }^{\circ}\right)$ for compound 2

$\begin{array}{llll}\mathrm{Ru}(1)-\mathrm{Ru}(2) & 2.840(2) & \mathrm{Ru}(1)-\mathrm{C}(2) & 2.28(2) \\ \mathrm{Ru}(2)-\mathrm{Ru}(3) & 2.909(2) & \mathrm{Ru}(1)-\mathrm{C}(3) & 2.30(1) \\ \mathrm{Ru}(3)-\mathrm{Ru}(4) & 2.831(3) & \mathrm{Ru}(4)-\mathrm{C}(7) & 2.28(1) \\ \mathrm{Ru}(1)-\mathrm{Ru}(4) & 2.795(2) & \mathrm{Ru}(4)-\mathrm{C}(6) & 2.36(2) \\ \mathrm{Ru}(1)-\mathrm{Ru}(5) & 2.844(2) & \mathrm{C}(2)-\mathrm{C}(3) & 1.39(2) \\ \mathrm{Ru}(2)-\mathrm{Ru}(5) & 2.772(2) & \mathrm{C}(3)-\mathrm{C}(4) & 1.50(2) \\ \mathrm{Ru}(3)-\mathrm{Ru}(5) & 2.793(2) & \mathrm{C}(4)-\mathrm{C}(5) & 1.43(2) \\ \mathrm{Ru}(4)-\mathrm{Ru}(5) & 2.864(2) & \mathrm{C}(5)-\mathrm{C}(6) & 1.48(2) \\ \mathrm{Ru}(1)-\mathrm{C}(1) & 2.01(1) & \mathrm{C}(6)-\mathrm{C}(7) & 1.40(2) \\ \mathrm{Ru}(2)-\mathrm{C}(1) & 2.03(1) & \mathrm{C}(2)-\mathrm{C}(7) & 1.43(2) \\ \mathrm{Ru}(3)-\mathrm{C}(1) & 2.01(1) & & \\ \mathrm{Ru}(4)-\mathrm{C}(1) & 2.02(1) & \mathrm{Ru}-\mathrm{C} \mathrm{Co}(\operatorname{mean}) & 1.91(2) \\ \mathrm{Ru}(5)-\mathrm{C}(1) & 2.12(1) & \mathrm{C} \mathrm{Co}-\mathrm{O}(\mathrm{Co}(\mathrm{mean}) & 1.13(2) \\ & & & \\ \mathrm{C}(2)-\mathrm{C}(3)-\mathrm{C}(4) & 120(1) & \mathrm{C}(5)-\mathrm{C}(6)-\mathrm{C}(7) & 120(1) \\ \mathrm{C}(3)-\mathrm{C}(4)-\mathrm{C}(5) & 116(1) & \mathrm{C}(6)-\mathrm{C}(7)-\mathrm{C}(2) & 119(1) \\ \mathrm{C}(4)-\mathrm{C}(5)-\mathrm{C}(6) & 116(1) & \mathrm{C}(7)-\mathrm{C}(2)-\mathrm{C}(3) & 121(1)\end{array}$

observed in the formation of cyclohexa-1,3-diene derivatives of the mononuclear unit $\mathrm{M}(\mathrm{CO})_{3}(\mathrm{M}=\mathrm{Fe}, \mathrm{Ru}$ or Os). The simplest mechanistic pathway might be taken to involve the sequential removal of a co-ordinated $\mathrm{CO}$ (by oxidation to $\mathrm{CO}_{2}$ by $\mathrm{Me}_{3} \mathrm{NO}$ ) followed by the addition of the diene via one olefin fragment in the first instance. The formation of 2 , in which the diene spans two ruthenium atoms, may reflect the activation by $\mathrm{Me}_{3} \mathrm{NO}$ of co-ordination sites on two adjacent ruthenium atoms rather than at a single metal site.

Compound 2 was found to react with a further equivalent of $\mathrm{Me}_{3} \mathrm{NO}$ in $\mathrm{CH}_{2} \mathrm{Cl}_{2}$ at ambient temperature to give the two isomeric benzene products, red $\left[\mathrm{Ru} \mathrm{u}_{5} \mathrm{C}(\mathrm{CO})_{12}\left(\mu_{3}-\eta^{2}: \eta^{2}: \eta^{2}\right.\right.$ $\left.\left.\mathrm{C}_{6} \mathrm{H}_{6}\right)\right]$ 3a and black $\left[\mathrm{Ru}_{5} \mathrm{C}(\mathrm{CO})_{12}\left(\eta^{6}-\mathrm{C}_{6} \mathrm{H}_{6}\right)\right]$ 3b. After removal of solvent under vacuum these isomers were readily separated by TLC on silica using dichloromethane-ethyl acetate-hexane $(2: 1: 17 \mathrm{v} / \mathrm{v})$. On warming, isomer $3 \mathrm{a}$ readily and irreversibly converts to $\mathbf{3 b}$. The observation that isomer $\mathbf{3 a}$ appears to be the first product of the reaction may be taken to reflect the co-ordination mode of the diene in 2 (see above).

The solid-state structures of the isomers $\mathbf{3 a}$ and $\mathbf{3 b}$, as established by single crystal X-ray diffraction, ${ }^{15}$ are shown in Figs. 2 and 3, respectively. Relevant bond distances are listed in Tables 3 and 4 . Since the important structural features of the two complexes have been previously described in a preliminary report, ${ }^{15}$ the following section will only briefly summarize the main structural differences between the two species. Both clusters are based on the same square-pyramidal metal framework seen in compounds 1 and 2 , with the C(carbide) atom roughly occupying the middle of the square base (but see also

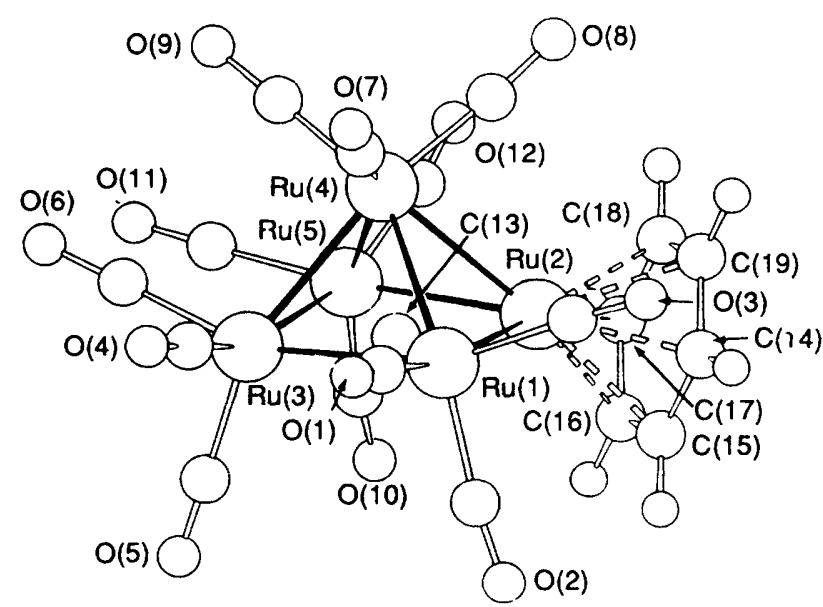

Fig. 3 The solid-state molecular structure of one of the two independent molecules present in the asymmetric unit of compound $\mathbf{3 b}$, showing the atomic labelling scheme; other detail as in Fig. 1

Table 3 Relevant bond distances $(\AA)$ for compound 3a

\begin{tabular}{|c|c|c|c|}
\hline $\mathrm{Ru}(1)-\mathbf{R u}(2)$ & $2.827(1)$ & $\mathrm{Ru}(1)-\mathrm{C}(18)$ & $2.23(1)$ \\
\hline Ru(1)-Ru(3) & $2.829(1)$ & $\mathrm{Ru}(2)-\mathrm{C}(19)$ & $2.31(1)$ \\
\hline$R u(1)-R u(4)$ & $2.800(1)$ & $\mathrm{Ru}(2)-\mathrm{C}(14)$ & $2.21(1)$ \\
\hline $\mathrm{Ru}(1)-\mathrm{Ru}(5)$ & $2.811(1)$ & $\mathrm{Ru}(3)-\mathrm{C}(15)$ & $2.26(1)$ \\
\hline $\mathrm{Ru}(2)-\mathrm{Ru}(3)$ & $2.845(1)$ & $\mathrm{Ru}(3)-\mathrm{C}(16)$ & $2.25(1)$ \\
\hline $\mathrm{Ru}(2)-\operatorname{Ru}(5)$ & $2.841(1)$ & & \\
\hline$R u(3)-R u(4)$ & $2.843(1)$ & $C(14)-C(15)$ & $1.45(1)$ \\
\hline$R u(4)-R u(5)$ & $2.827(1)$ & $C(15)-C(16)$ & $1.34(1)$ \\
\hline $\mathrm{Ru}(1)-\mathrm{C}(13)$ & $2.09(1)$ & $C(16)-C(17)$ & $1.46(2)$ \\
\hline $\mathbf{R u}(2)-\mathrm{C}(13)$ & $2.02(1)$ & $C(17)-C(18)$ & $1.36(2)$ \\
\hline $\mathrm{Ru}(3)-\mathrm{C}(13)$ & $2.00(1)$ & $C(18)-C(19)$ & $1.42(1)$ \\
\hline $\mathrm{Ru}(4)-\mathrm{C}(13)$ & $2.02(1)$ & $C(14)-C(19)$ & $1.38(1)$ \\
\hline $\mathrm{Ru}(5)-\mathrm{C}(13)$ & $2.01(1)$ & $\mathrm{Ru}-\mathrm{C}_{\mathrm{Co}}$ (mean) & $1.90(1)$ \\
\hline $\operatorname{Ru}(1)-C(17)$ & $2.31(1)$ & $\mathrm{C}_{\mathrm{co}}-\mathrm{O}_{\mathrm{Co}}$ (mean) & $1.13(1)$ \\
\hline
\end{tabular}

Table 4 Relevant bond distances $(\AA)$ for compound 3b

\begin{tabular}{|c|c|c|}
\hline & Molecule A & Molecule B \\
\hline $\operatorname{Ru}(1)-\mathbf{R u}(2)$ & $2.847(2)$ & $2.873(2)$ \\
\hline $\operatorname{Ru}(1)-\operatorname{Ru}(3)$ & $2.800(2)$ & $2.769(2)$ \\
\hline$R u(1)-R u(4)$ & $2.774(2)$ & $2.793(2)$ \\
\hline $\mathrm{Ru}(1)-\mathrm{Ru}(5)$ & $2.744(2)$ & $2.732(2)$ \\
\hline $\operatorname{Ru}(2)-\operatorname{Ru}(3)$ & $2.807(2)$ & $2.797(2)$ \\
\hline $\mathrm{Ru}(3)-\mathrm{Ru}(4)$ & $2.856(2)$ & $2.858(2)$ \\
\hline$R u(4)-R u(5)$ & $2.865(2)$ & $2.887(2)$ \\
\hline $\operatorname{Ru}(2)-\operatorname{Ru}(5)$ & $2.791(2)$ & $2.797(2)$ \\
\hline $\mathrm{Ru}(1)-\mathrm{C}(13)$ & $2.09(2)$ & $2.13(2)$ \\
\hline $\mathrm{Ru}(2)-\mathrm{C}(13)$ & $1.93(2)$ & $1.86(2)$ \\
\hline $\mathrm{Ru}(3)-\mathrm{C}(13)$ & $2.00(2)$ & $2.04(2)$ \\
\hline $\mathrm{Ru}(4)-\mathrm{C}(13)$ & $2.02(2)$ & $2.07(2)$ \\
\hline $\operatorname{Ru}(5)-C(13)$ & $2.07(2)$ & $2.07(2)$ \\
\hline $\mathrm{Ru}(2)-\mathrm{C}(14)$ & $2.25(1)$ & $2.21(2)$ \\
\hline $\mathrm{Ru}(2)-\mathrm{C}(15)$ & $2.23(1)$ & $2.21(2)$ \\
\hline $\mathrm{Ru}(2)-\mathrm{C}(16)$ & $2.21(1)$ & $2.22(2)$ \\
\hline $\mathrm{Ru}(2)-\mathrm{C}(17)$ & $2.21(1)$ & $2.24(1)$ \\
\hline $\mathrm{Ru}(2)-\mathrm{C}(18)$ & $2.22(1)$ & $2.24(1)$ \\
\hline $\operatorname{Ru}(2)-C(19)$ & $2.24(1)$ & $2.23(2)$ \\
\hline $\mathrm{Ru}-\mathrm{C}_{\mathrm{co}}($ mean $)$ & $1.90(2)$ & $1.91(2)$ \\
\hline $\mathrm{C}_{\mathrm{CO}}-\mathrm{O}_{\mathrm{Co}}($ mean $)$ & $1.14(3)$ & $1.13(3)$ \\
\hline
\end{tabular}

below). The most striking difference between the two structures arises essentially from the mode of co-ordination of the benzene fragment, which is face-capping ( $\mu_{3}$ bonding) in $\mathbf{3 a}$ and terminal ( $\eta^{6}$ bonding) in 3b. This is the first report of the synthesis and full structural characterization of two structural isomers containing benzene in both bonding modes. 
Face-capping of a cluster frame by benzene is not very common. This co-ordination mode has been previously observed only in the trinuclear species $\left[\mathrm{M}_{3}(\mathrm{CO})_{9}\left(\mu_{3}-\eta^{2}: \eta^{2}: \eta^{2}-\right.\right.$ $\left.\left.\mathrm{C}_{6} \mathrm{H}_{6}\right)\right]\left(\mathrm{M}=\mathrm{Ru}^{1}\right.$ and $\left.\mathrm{Os}^{8}\right)$ and $\left[\mathrm{Os}_{3}(\mathrm{CO})_{8}\left(\eta^{2}-\mathrm{C}_{2} \mathrm{H}_{2}\right)\left(\mu_{3}\right.\right.$. $\left.\left.\eta^{2}: \eta^{2}: \eta^{2}-\mathrm{C}_{6} \mathrm{H}_{6}\right)\right]^{2}$ and in the hexanuclear carbidocarbonyl cluster $\left[\mathrm{Ru}_{6} \mathrm{C}(\mathrm{CO})_{11}\left(\eta^{6}-\mathrm{C}_{6} \mathrm{H}_{6}\right)\left(\mu_{3}-\eta^{2}: \eta^{2}: \eta^{2}-\mathrm{C}_{6} \mathrm{H}_{6}\right)\right]{ }^{8} \mathrm{~A}$ facecapping arene has also been observed in the cobalt cluster $\left[\mathrm{Co}\left(\eta^{5}-\mathrm{C}_{5} \mathrm{H}_{5}\right)_{3}\left(\mu_{3}-\eta^{2}: \eta^{2}: \eta^{2}-\mathrm{C}_{6} \mathrm{H}_{5} \mathrm{CH}=\mathrm{CHMe}\right)\right]{ }^{16}$ The $\eta^{6}$ co-ordination found in compound $\mathbf{3 b}$ is more common. The benzene ligand formally replaces one tricarbonyl unit in the ligand envelope as observed in several arene derivatives of the octahedral cluster $\left[\mathrm{Ru}_{6} \mathrm{C}(\mathrm{CO})_{17}\right]$ \{including $\left[\mathrm{Ru} \mathrm{C}_{6} \mathrm{C}(\mathrm{CO})_{11^{-}}\right.$$\left.\left(\eta^{6}-\mathrm{C}_{6} \mathrm{H}_{6}\right)\left(\mu_{3}-\eta^{2}: \eta^{2}: \eta^{2}-\mathrm{C}_{6} \mathrm{H}_{6}\right)\right]$ mentioned above $\left.{ }^{8}\right\}$ and in the recently reported trinuclear species $\left[\mathrm{Ru}_{3}(\mathrm{CO})_{7}\left(\mu_{3}-\eta^{2}-\mathrm{C}_{2}-\right.\right.$ $\left.\left.\mathrm{Ph}_{2} \mathrm{CO}\right)\left(\eta^{6}-\mathrm{C}_{6} \mathrm{H}_{6}\right)\right]^{3 b}$ and $\left[\mathrm{Os}_{3}(\mathrm{CO})_{8}\left(\mu_{3}-\eta^{2}-\mathrm{C}_{2} \mathrm{Me}_{2}\right)\left(\eta^{6}-\mathrm{C}_{6}-\right.\right.$ $\left.\left.\mathrm{H}_{6}\right)\right]{ }^{3 a}$

At no stage during the formation of compounds $\mathbf{3 a}$ and $\mathbf{3 b}$ from compound 2 was observed the formation of the expected hexadienyl derivative $\left[\mathrm{Ru}_{5} \mathrm{HC}(\mathrm{CO})_{12}\left(\mathrm{C}_{6} \mathrm{H}_{7}\right)\right]$ 5. The first step in this reaction sequence may be envisaged as the creation of a vacant co-ordination site within the $\mathrm{Ru}_{5} \mathrm{C}$ unit by the oxidation of $\mathrm{CO}$ to $\mathrm{CO}_{2}$ by $\mathrm{Me}_{3} \mathrm{NO}$, followed by the oxidative addition of a $\mathrm{C}-\mathrm{H}$ bond of the diene to generate the hydridohexadienyl cluster 5 . The required second $\mathbf{C}-\mathrm{H}$ bond cleavage must occur

Table 5 Relevant bond distances $(\AA)$ for compound $4 a$

$\begin{array}{llll}\mathrm{Ru}(1)-\mathrm{Ru}(3) & 2.837(2) & \mathrm{Ru}(1)-\mathrm{Ru}(4) & 2.732(2) \\ \mathrm{Ru}(1)-\mathrm{Ru}(5) & 2.870(2) & \mathrm{Ru}(2)-\mathrm{Ru}(3) & 2.872(2) \\ \mathrm{Ru}(2)-\mathrm{Ru}(5) & 2.859(2) & \mathrm{Ru}(3)-\mathrm{Ru}(4) & 2.877(2) \\ \mathrm{Ru}(4)-\mathrm{Ru}(5) & 2.865(2) & \mathrm{Ru}(2)-\mathrm{C}(14) & 2.07(1) \\ \mathrm{Ru}(1)-\mathrm{C}(14) & 2.10(1) & \mathrm{Ru}(4)-\mathrm{C}(14) & 2.04(1) \\ \mathrm{Ru}(3)-\mathrm{C}(14) & 1.97(1) & \mathrm{Ru}(2)-\mathrm{C}(15) & 2.32(1) \\ \mathrm{Ru}(5)-\mathrm{C}(14) & 1.99(1) & \mathrm{Ru}(2)-\mathrm{C}(17) & 2.23(1) \\ \mathrm{Ru}(2)-\mathrm{C}(16) & 2.27(1) & \mathrm{Ru}(2)-\mathrm{C}(19) & 2.29(1) \\ \mathrm{Ru}(2)-\mathrm{C}(18) & 2.24(1) & & \\ \mathrm{Ru}(2)-\mathrm{C}(20) & 2.33(1) & & \\ \mathrm{Ru}-\mathrm{C}_{\mathrm{Co}}(\text { mean }) & 1.88(2) & \mathrm{C}_{\mathrm{Co}}-\mathrm{O}_{\mathrm{co}}(\text { mean) } & 1.15(2)\end{array}$

by an alternative route since only one equivalent of $\mathrm{Me}_{3} \mathrm{NO}$ is required. We may speculate that this essential second cleavage is brought about by an initial cluster rearrangement, possibly a square-pyramidal to bridged-butterfly interconversion, during which an activated co-ordination site is generated, which is then followed by the required $\mathrm{C}-\mathrm{H}$ bond cleavage. This process will generate the second possible bridged-butterfly intermediate $\left[\mathrm{Ru}_{5} \mathrm{H}_{2} \mathrm{C}(\mathrm{CO})_{12}\left(\mathrm{C}_{6} \mathrm{H}_{6}\right)\right]$. Dihydrogen is then evolved and the square-pyramidal $\mathrm{Ru}_{5} \mathrm{C}$ unit regenerated. In this overall mechanistic pathway the dienyl derivative 5 is expected to be $\mu_{3}$ bonded across a $\mathrm{Ru}_{3}$ triangular face.

Treatment of compound $\mathbf{3 b}$ with carbon monoxide under ambient conditions produces the new cluster $\left[\mathrm{Ru} \mathrm{H}_{5} \mathrm{C}(\mathrm{CO})_{13^{-}}\right.$ $\left.\left(\eta^{6}-\mathrm{C}_{6} \mathrm{H}_{6}\right)\right]$ 4a. In this reaction $\mathrm{CO}$ addition has apparently occurred at the basal ruthenium atom which supports the benzene molecule. Just as in the reaction of $\left[\mathrm{Ru}_{5} \mathrm{C}(\mathrm{CO})_{15}\right]$ with $\mathrm{CO}$ or $\mathrm{MeCN}$, we have been able to establish by single

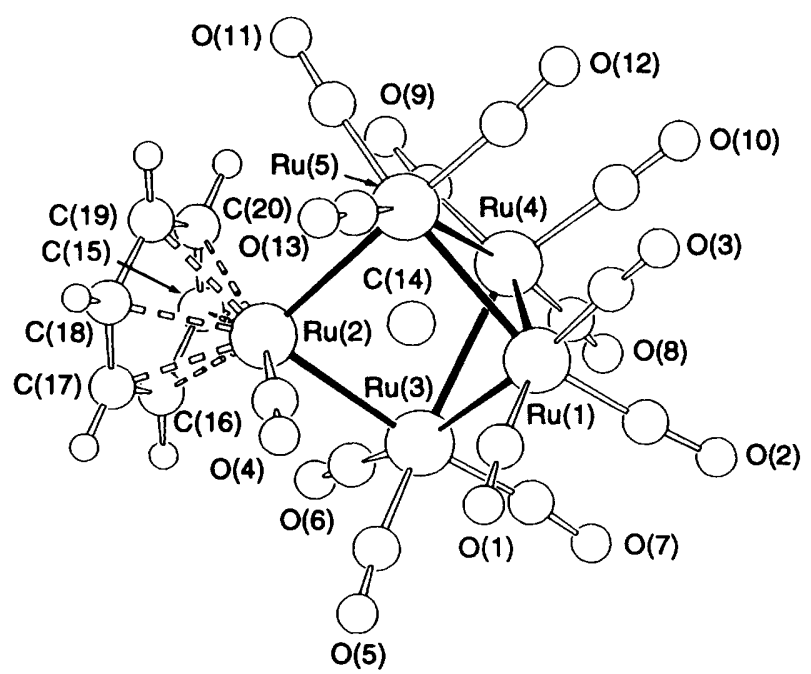

Fig. 4 The solid-state molecular structure of compound $\mathbf{4 a}$, showing the atomic labelling scheme; other detail as in Fig. 1

Table 6 Crystal data and measurement details for compounds $2,3 \mathrm{a}, 3 \mathrm{~b}$ and $4 \mathrm{a}^{\mathrm{a}}$

\begin{tabular}{|c|c|c|c|c|}
\hline & 2 & $\mathbf{3 a}$ & $\mathbf{3 b}$ & $4 \mathbf{a}$ \\
\hline Formula & $\begin{array}{l}\mathrm{C}_{20.25} \mathrm{H}_{8.5} \mathrm{Cl}_{0.5} \mathrm{O}_{15} \mathrm{Ru}_{5} \\
10145\end{array}$ & $\begin{array}{l}\mathrm{C}_{19} \mathrm{H}_{6} \mathrm{O}_{12} \mathrm{Ru}_{5} \\
931.6\end{array}$ & $\begin{array}{l}\mathrm{C}_{19} \mathrm{H}_{6} \mathrm{O}_{12} \mathrm{Ru}_{5} \\
931.6\end{array}$ & $\begin{array}{l}\mathrm{C}_{20} \mathrm{H}_{6} \mathrm{O}_{13} \mathrm{Ru}_{5} \\
959.6\end{array}$ \\
\hline Crystal size $/ \mathrm{mm}$ & $0.25 \times 0.27 \times 0.42$ & $0.13 \times 0.16 \times 0.14$ & $0.12 \times 0.11 \times 0.15$ & $0.2 \times 0.25 \times 0.13$ \\
\hline System & Monoclinic & Triclinic & Monoclinic & Monoclinic \\
\hline Space group & $P 2_{1} / n$ & $P \mathrm{~T}$ & $P 2_{1} / c$ & $P 2_{1} / n$ \\
\hline$a / \AA$ & $16.193(3)$ & $9.525(2)$ & $15.26(2)$ & $9.792(4)$ \\
\hline$b / \AA$ & $9.897(2)$ & $14.574(3)$ & $16.675(9)$ & $15.718(2)$ \\
\hline$c / \AA \AA$ & $19.536(4)$ & $9.484(4)$ & $19.016(9)$ & $16.446(3)$ \\
\hline$\alpha /^{\circ}$ & & $96.29(2)$ & & \\
\hline$\beta / /^{\circ}$ & $98.80(3)$ & $112.37(3)$ & $96.04(7)$ & $96.37(2)$ \\
\hline$\gamma /{ }^{\circ}$ & & $82.33(2)$ & & \\
\hline$U / \AA^{3}$ & 3092 & 1204 & 4812 & 2515 \\
\hline$Z$ & 4 & 2 & 8 & 4 \\
\hline$F(000)$ & 1962 & 872 & 3488 & 1800 \\
\hline$D_{\mathrm{c}} / \mathrm{g} \mathrm{cm}^{-3}$ & 2.19 & 2.57 & 2.57 & 2.54 \\
\hline$\mu(\mathrm{Mo}-\mathrm{K} \alpha) / \mathrm{cm}^{-1}$ & 24.3 & 28.40 & 28.43 & 27.2 \\
\hline $2 \theta$ Range $/^{\circ}$ & $7-45$ & $6-56$ & $5-50$ & $6-50$ \\
\hline$\omega$ Scan width $/^{\circ}$ & 1.40 & 1.40 & 0.90 & 1.2 \\
\hline Maximum scan time/s & & 90 & 90 & 100 \\
\hline Measured reflections & 5113 & 6415 & 7726 & 4752 \\
\hline Unique observed reflections $[I>2 \sigma(I)]$ & 2886 & 4114 & 3951 & 2037 \\
\hline No. of refined parameters & 256 & 331 & 571 & 302 \\
\hline$R, R^{\prime b}$ & $0.061,0.78$ & $0.040,0.040$ & $0.058,0.060$ & $0.039,0.042$ \\
\hline Goodness of fit & 1.4 & 1.1 & 2.5 & 1.3 \\
\hline$g$ & 0.002 & 0.0010 & 0.0009 & 0.0004 \\
\hline $\begin{array}{l}\sigma \\
k\end{array}$ & 1 & 0.7 & 1.01 & 1.12 \\
\hline
\end{tabular}

a Details common to the determinations of 3a, 3b and 4a: requested counting $[\sigma(I) / I]=0.02$, prescan rate $=3^{\circ} \min ^{-1}$ and prescan acceptance $[\sigma(I) / I]=0.5 .^{b} R^{\prime}=\Sigma\left[\left(F_{\mathrm{o}}-F_{\mathrm{c}}\right) w^{\frac{1}{t}}\right] / \Sigma F_{\mathrm{o}} w^{\frac{1}{2}}$, where $w=k /\left[\sigma(F)+|g| F^{2}\right]$. 
Table 7 Fractional atomic coordinates $\left(\times 10^{4}\right)$ for compound 2

$\begin{array}{lccl}\text { Atom } & x & y & z \\ \mathrm{Ru}(1) & 1259(1) & 1062(1) & 3564(1) \\ \mathrm{Ru}(2) & 392(1) & 642(1) & 2846(1) \\ \mathrm{Ru}(3) & -774(1) & 3424(1) & 3163(1) \\ \mathrm{Ru}(4) & 901(1) & 3755(1) & 3815(1) \\ \mathrm{Ru}(5) & 518(1) & 2775(1) & 2423(1) \\ \mathrm{C}(1) & 212(8) & 2177(14) & 3398(7) \\ \mathrm{C}(2) & 2492(9) & 2217(15) & 3695(8) \\ \mathrm{C}(3) & 2513(10) & 1348(16) & 4258(8) \\ \mathrm{C}(4) & 2442(11) & 1914(16) & 4960(8) \\ \mathrm{C}(5) & 2541(11) & 3346(17) & 5035(9) \\ \mathrm{C}(6) & 2259(10) & 4163(16) & 4409(8) \\ \mathrm{C}(7) & 2291(9) & 3619(15) & 3750(8) \\ \mathrm{C}(11) & 1736(9) & -435(16) & 3098(7) \\ \mathrm{O}(11) & 2033(8) & -1277(11) & 2845(6) \\ \mathrm{C}(12) & 1076(10) & -14(16) & 4300(8) \\ \mathrm{O}(12) & 912(7) & -669(11) & 4753(6) \\ \mathrm{C}(21) & 66(11) & -776(17) & 2384(9) \\ \mathrm{O}(21) & 307(8) & -1623(15) & 2104(8) \\ \mathrm{C}(22) & -810(10) & -452(17) & 3533(8) \\ \mathrm{O}(22) & -1055(8) & -1075(12) & 3937(6) \\ \mathrm{C}(23) & -1404(10) & 511(16) & 2195(8) \\ \mathrm{O}(23) & -1975(8) & 387(13) & 1803(6) \\ \mathrm{C}(31) & -1266(10) & 3416(16) & 4006(9) \\ \mathrm{O}(31) & -1539(8) & 3510(13) & 4504(6) \\ \mathrm{C}(32) & -1794(11) & 3204(16) & 2541(8) \\ \mathrm{O}(32) & -2422(8) & 3124(14) & 2185(7) \\ \mathrm{C}(33) & -842(10) & 5352(17) & 3006(8) \\ \mathrm{O}(33) & -898(8) & 6467(11) & 2896(7) \\ \mathrm{C}(41) & 674(9) & 3696(15) & 4739(8) \\ \mathrm{O}(41) & 509(7) & 3646(11) & 5269(5) \\ \mathrm{C}(42) & 864(9) & 5707(16) & 3752(8) \\ \mathrm{O}(42) & 837(8) & 6849(11) & 3704(6) \\ \mathrm{C}(51) & 958(10) & 4536(17) & 2305(8) \\ \mathrm{O}(51) & 1220(7) & 5558(11) & 2202(6) \\ \mathrm{C}(52) & -349(10) & 2777(17) & 1656(8) \\ \mathrm{O}(52) & -834(8) & 2762(16) & 1171(6) \\ \mathrm{C}(53) & 1340(10) & 1830(16) & 1999(8) \\ \mathrm{O}(53) & 1813(8) & 1318(12) & 1721(6) \\ \mathrm{Cl}(1) & 8073(17) & 6184(27) & 1179(14) \\ \mathrm{Cl}(2) & 8345(21) & 7291(34) & -61(16) \\ \mathrm{C}(100) & 8738(64) & 7137(106) & 677(52)\end{array}$

crystal $\mathrm{X}$-ray diffraction studies that the $\mathrm{Ru}_{5} \mathrm{C}$ polyhedron undergoes conversion from a square-based pyramid to a bridged-butterfly arrangement.

The molecular structure of compound $4 a$ is shown in Fig. 4 together with the atomic labelling scheme. Relevant bond distances are listed in Table 5. The metal-atom framework can be described as a bridged-butterfly. This cluster can be seen as being formally derived from the square-pyramidal geometry of compound $3 \mathrm{~b}$ by opening up one apex-to-base linkage upon $\mathrm{CO}$ insertion on the basal Ru atom bearing the benzene ligand. The bridging $\mathrm{Ru}(2)$ atom is almost equidistant from the two ruthenium atoms of the butterfly hinge $[R u(1) \cdots R u(2)$ 3.919 (2) and $R u(2) \ldots R u(4) 3.819(2) \AA]$. The $R u-R u$ bond lengths in 4a range from $2.732(2)$ to $2.877(2) \AA$ and are slightly longer, in their mean value, than in $3 \mathrm{~b}$ [2.844(2) versus $2.812(2)$ $\AA]$. Each ruthenium atom, except $\mathrm{Ru}(2)$, bears three $\mathrm{CO}$ groups as in the parent molecule. The $\mathrm{Ru}(2)$ atom formally receives two electrons more than the other metal atoms (six from benzene and two from the single CO ligand) but is involved in only two metal-metal interactions. Interestingly, the drift of the C(carbide) atom towards the arene-co-ordinated metal atom, observed in compound $\mathbf{3 b}$, is not seen in $\mathbf{4 a}$. This observation confirms that the C(carbide) atom 'comes to help' if complete substitution of $\mathrm{CO}$ ligands for the less efficient $\pi$-acceptor benzene ligand deprives the metal atom of electron density. This is not so for $\mathrm{Ru}(2)$ in $\mathbf{4 a}$, where the presence of the extra $\mathrm{CO}$
Table 8 Fractional atomic coordinates for compound 32

\begin{tabular}{llll} 
Atom & \multicolumn{1}{l}{$y$} & \multicolumn{1}{l}{$y$} \\
$\mathrm{Ru}(1)$ & $0.70695(5)$ & $0.35248(3)$ & $0.73643(5)$ \\
$\mathrm{Ru}(2)$ & $0.94913(5)$ & $0.21379(3)$ & $0.85952(6)$ \\
$\mathrm{Ru}(3)$ & $0.64178(5)$ & $0.16949(3)$ & $0.74243(6)$ \\
$\mathrm{Ru}(4)$ & $0.59148(5)$ & $0.24523(3)$ & $0.46139(5)$ \\
$\mathrm{Ru}(5)$ & $0.89852(5)$ & $0.28599(3)$ & $0.57595(6)$ \\
$\mathrm{C}(1)$ & $0.5115(8)$ & $0.4141(4)$ & $0.6292(8)$ \\
$\mathrm{O}(1)$ & $0.3946(6)$ & $0.4523(4)$ & $0.5712(7)$ \\
$\mathrm{C}(2)$ & $0.8068(8)$ & $0.4589(5)$ & $0.7477(9)$ \\
$\mathrm{O}(2)$ & $0.8666(8)$ & $0.5239(4)$ & $0.7628(8)$ \\
$\mathrm{C}(3)$ & $1.0340(9)$ & $0.0905(5)$ & $0.8641(9)$ \\
$\mathrm{O}(3)$ & $1.0835(9)$ & $0.0148(5)$ & $0.8683(9)$ \\
$\mathrm{C}(4)$ & $1.1504(9)$ & $0.2467(6)$ & $0.9659(9)$ \\
$\mathrm{O}(4)$ & $1.2723(7)$ & $0.2625(7)$ & $1.0287(8)$ \\
$\mathrm{C}(5)$ & $0.6944(9)$ & $0.0403(5)$ & $0.7402(11)$ \\
$\mathrm{O}(5)$ & $0.7287(9)$ & $-0.0375(4)$ & $0.7385(10)$ \\
$\mathrm{C}(6)$ & $0.4333(8)$ & $0.1481(5)$ & $0.6843(10)$ \\
$\mathrm{O}(6)$ & $0.3124(6)$ & $0.1342(5)$ & $0.6581(9)$ \\
$\mathrm{C}(7)$ & $0.3784(8)$ & $0.2474(5)$ & $0.4186(8)$ \\
$\mathrm{O}(7)$ & $0.2493(6)$ & $0.2524(4)$ & $0.3843(7)$ \\
$\mathrm{C}(8)$ & $0.5969(8)$ & $0.1386(5)$ & $0.3304(9)$ \\
$\mathrm{O}(8)$ & $0.6046(9)$ & $0.0748(4)$ & $0.2551(8)$ \\
$\mathrm{C}(9)$ & $0.5518(8)$ & $0.3300(5)$ & $0.3070(7)$ \\
$\mathrm{O}(9)$ & $0.5202(7)$ & $0.3797(4)$ & $0.2134(6)$ \\
$\mathrm{C}(10)$ & $0.8663(8)$ & $0.3747(5)$ & $0.4254(8)$ \\
$\mathrm{O}(10)$ & $0.8564(8)$ & $0.4267(4)$ & $0.3442(7)$ \\
$\mathrm{C}(11)$ & $0.9714(8)$ & $0.1831(6)$ & $0.4744(9)$ \\
$\mathrm{O}(11)$ & $1.0059(7)$ & $0.1193(5)$ & $0.4135(8)$ \\
$\mathrm{C}(12)$ & $1.0947(8)$ & $0.3279(6)$ & $0.6878(9)$ \\
$\mathrm{O}(12)$ & $1.2076(7)$ & $0.3579(5)$ & $0.7436(9)$ \\
$\mathrm{C}(13)$ & $0.7736(6)$ & $0.2212(3)$ & $0.6562(6)$ \\
$\mathrm{C}(14)$ & $0.8816(10)$ & $0.2133(6)$ & $1.0579(9)$ \\
$\mathrm{C}(15)$ & $0.7290(11)$ & $0.1848(6)$ & $0.9999(9)$ \\
$\mathrm{C}(16)$ & $0.6060(9)$ & $0.2462(8)$ & $0.9467(10)$ \\
$\mathrm{C}(17)$ & $0.6254(14)$ & $0.3421(8)$ & $0.9336(11)$ \\
$\mathrm{C}(18)$ & $0.7675(15)$ & $0.3706(6)$ & $0.9889(9)$ \\
$\mathrm{C}(19)$ & $0.8955(11)$ & $0.3053(8)$ & $1.0505(10)$ \\
& & &
\end{tabular}

ligand appears to compensate for this effect, or in the facecapped 3a where the effect is distributed over three metal atoms. Consistent with this, $\mathrm{Ru}-\mathrm{C}$ (benzene) distances in 4a appear to be slightly longer, in their mean value, than in $3 b$ [2.28(1) versus 2.23(1) $\AA]$.

On standing, freshly prepared samples of compound $\mathbf{4 a}$ readily evolve carbon monoxide to regenerate the initial compound $3 \mathrm{~b}$. If, however, $4 \mathrm{a}$ is prepared and stored at $-20^{\circ} \mathrm{C}$ for $24 \mathrm{~h}$ under a $\mathrm{CO}$ atmosphere, on removal of the $\mathrm{CO}$ at the same temperature under nitrogen, a third, new isomer of $\left[\mathrm{Ru}{ }_{5} \mathrm{C}(\mathrm{CO})_{12}\left(\mathrm{C}_{6} \mathrm{H}_{6}\right)\right] 3 \mathrm{c}$ is produced. All attempts to obtain crystals of this new isomer have failed and have led to the isolation of crystals of the established isomer $\mathbf{3 b}$. However, since the IR spectra of the compounds are clearly different, we are inclined to suggest that the new isomer $3 \mathrm{c}$ is based on the same square-pyramidal $\mathrm{Ru}_{5}$ unit but that the benzene molecule is coordinated to the apical ruthenium atom. Alternatively, $3 c$ may possess a structure simply derived from $3 \mathrm{~b}$ by opening one $\mathrm{Ru}-\mathrm{Ru}$ edge to form a bridged-butterfly $\mathrm{Ru}_{5} \mathrm{C}$ arrangement which is stabilized by donation of a carbonyl oxygen to form a $\mathrm{Ru}-\mathrm{C}-\mathrm{O}-\mathrm{Ru}$ bridge. It would appear that the thermodynamically stable isomer is $\mathbf{3 b}$ but that isomer $3 \mathrm{c}$ is the kinetically controlled product. If $3 \mathrm{c}$ is heated in hexane for $c a$. $40 \mathrm{~h}$ then conversion to the isomer $3 \mathrm{~b}$ is observed.

It is clear that, given these observations, the reaction of isomer 3b with $\mathrm{CO}$ is not simple. This leads us to suggest that attack by $\mathrm{CO}$ may occur either at more than one ruthenium site (Scheme 2) at substantially different rates or that $\mathrm{CO}$ attack initially occurs at one site and is followed by a slow isomerisation process involving $\mathrm{CO}$ migration. Possible mechanistic pathways are shown in Schemes 2 and 3. Given that compound $3 \mathbf{b}$ appears to be the thermodynamically stable 
Table 9 Fractional atomic coordinates for compound $\mathbf{3 b}$

$\begin{array}{llll}\text { Atom } & x & y & z \\ \mathrm{Ru}(1 \mathrm{~A}) & 0.95185(10) & 0.30720(8) & 0.77175(9) \\ \mathrm{Ru}(2 \mathrm{~A}) & 0.85573(10) & 0.17044(8) & 0.80991(9) \\ \mathrm{Ru}(3 \mathrm{~A}) & 0.85410(10) & 0.31299(9) & 0.88825(9) \\ \mathrm{Ru}(4 \mathrm{~A}) & 0.79672(10) & 0.39520(8) & 0.75986(9) \\ \mathrm{Ru}(5 \mathrm{~A}) & 0.81357(10) & 0.25011(9) & 0.68175(9) \\ \mathrm{O}(1 \mathrm{~A}) & 1.0585(10) & 0.4255(9) & 0.8689(10) \\ \mathrm{O}(2 \mathrm{~A}) & 1.0879(10) & 0.1746(9) & 0.7721(11) \\ \mathrm{O}(3 \mathrm{~A}) & 1.0056(11) & 0.3819(9) & 0.6362(10) \\ \mathrm{O}(4 \mathrm{~A}) & 0.8878(15) & 0.4642(8) & 0.9730(9) \\ \mathrm{O}(5 \mathrm{~A}) & 0.6907(12) & 0.2723(16) & 0.9574(14) \\ \mathrm{O}(6 \mathrm{~A}) & 0.9729(9) & 0.2234(10) & 0.9963(10) \\ \mathrm{O}(7 \mathrm{~A}) & 0.8388(12) & 0.5504(7) & 0.8359(8) \\ \mathrm{O}(8 \mathrm{~A}) & 0.5996(11) & 0.4149(9) & 0.7524(11) \\ \mathrm{O}(9 \mathrm{~A}) & 0.8164(15) & 0.4943(9) & 0.6252(10) \\ \mathrm{O}(10 \mathrm{~A}) & 0.6384(11) & 0.1741(10) & 0.6596(10) \\ \mathrm{O}(11 \mathrm{~A}) & 0.7915(11) & 0.3481(10) & 0.5436(10) \\ \mathrm{O}(12 \mathrm{~A}) & 0.9247(13) & 0.1248(9) & 0.6153(10) \\ \mathrm{C}(1 \mathrm{~A}) & 1.0153(14) & 0.3808(12) & 0.8298(13) \\ \mathrm{C}(2 \mathrm{~A}) & 1.0355(13) & 0.2222(11) & 0.7734(13) \\ \mathrm{C}(3 \mathrm{~A}) & 0.9852(13) & 0.3527(12) & 0.6883(16) \\ \mathrm{C}(4 \mathrm{~A}) & 0.8757(16) & 0.4108(8) & 0.9389(11) \\ \mathrm{C}(5 \mathrm{~A}) & 0.7497(17) & 0.2923(16) & 0.9311(15) \\ \mathrm{C}(6 \mathrm{~A}) & 0.9327(16) & 0.2561(12) & 0.9565(14) \\ \mathrm{C}(7 \mathrm{~A}) & 0.8253(14) & 0.4913(8) & 0.8104(9) \\ \mathrm{C}(8 \mathrm{~A}) & 0.6719(14) & 0.4063(11) & 0.7542(12) \\ \mathrm{C}(9 \mathrm{~A}) & 0.8107(15) & 0.4561(13) & 0.6772(14) \\ \mathrm{C}(10 \mathrm{~A}) & 0.7018(16) & 0.2050(13) & 0.6644(12) \\ \mathrm{C}(11 \mathrm{~A}) & 0.7978(15) & 0.3123(11) & 0.5936(14) \\ \mathrm{C}(12 \mathrm{~A}) & 0.8852(14) & 0.1683(11) & 0.6443(9) \\ \mathrm{C}(13 \mathrm{~A}) & 0.8220(9) & 0.2797(10) & 0.7879(10) \\ \mathrm{C}(14 \mathrm{~A}) & 0.8717(9) & 0.0875(8) & 0.9035(6) \\ \mathrm{C}(15 \mathrm{~A}) & 0.7832(9) & 0.0886(8) & 0.8763(6) \\ \mathrm{C}(16 \mathrm{~A}) & 0.7594(9) & 0.0710(8) & 0.8051(6) \\ \mathrm{C}(17 \mathrm{~A}) & 0.8241(9) & 0.0524(8) & 0.7611(6) \\ \mathrm{C}(18 \mathrm{~A}) & 0.9126(9) & 0.0513(8) & 0.7883(6) \\ \mathrm{C}(19 \mathrm{~A}) & 0.9364(9) & 0.0688(8) & 0.8595(6)\end{array}$

\begin{tabular}{|c|c|c|c|}
\hline Atom & $x$ & $y$ & $z$ \\
\hline $\mathrm{Ru}(1 \mathrm{~B})$ & $0.28972(10)$ & $0.27210(8)$ & $0.40929(9)$ \\
\hline $\mathrm{Ru}(2 \mathrm{~B})$ & $0.31982(10)$ & $0.28340(8)$ & $0.56066(9)$ \\
\hline $\mathrm{Ru}(3 \mathrm{~B})$ & $0.30061(10)$ & $0.13509(8)$ & $0.49202(9)$ \\
\hline $\mathrm{Ru}(4 \mathrm{~B})$ & $0.44290(10)$ & $0.17979(9)$ & $0.41370(10)$ \\
\hline $\mathrm{Ru}(5 \mathrm{~B})$ & $0.44137(10)$ & $0.33962(9)$ & $0.47192(10)$ \\
\hline$O(1 B)$ & $0.2110(9)$ & $0.1536(9)$ & $0.3009(8)$ \\
\hline $\mathrm{O}(2 \mathrm{~B})$ & $0.1258(9)$ & $0.3560(10)$ & $0.4491(10)$ \\
\hline$O(3 B)$ & $0.3265(11)$ & $0.3913(8)$ & $0.2989(7)$ \\
\hline $\mathrm{O}(4 \mathrm{~B})$ & $0.2577(10)$ & $-0.0146(7)$ & $0.4054(9)$ \\
\hline $\mathrm{O}(5 \mathrm{~B})$ & $0.3774(12)$ & $0.0408(11)$ & $0.6196(9)$ \\
\hline $\mathrm{O}(6 \mathrm{~B})$ & $0.1106(10)$ & $0.1472(8)$ & $0.5246(10)$ \\
\hline $\mathrm{O}(7 \mathrm{~B})$ & $0.3957(12)$ & $0.0437(11)$ & $0.3107(11)$ \\
\hline $\mathrm{O}(8 \mathrm{~B})$ & $0.5788(12)$ & $0.0869(11)$ & $0.5049(14)$ \\
\hline$O(9 B)$ & $0.5499(13)$ & $0.2529(12)$ & $0.3034(12)$ \\
\hline $\mathrm{O}(10 \mathrm{~B})$ & $0.5868(11)$ & $0.3507(11)$ & $0.5894(8)$ \\
\hline $\mathrm{O}(11 \mathrm{~B})$ & $0.5438(13)$ & $0.4209(11)$ & $0.3610(11)$ \\
\hline $\mathrm{O}(12 \mathrm{~B})$ & $0.3504(11)$ & $0.4987(8)$ & $0.4966(8)$ \\
\hline$C(1 B)$ & $0.2413(12)$ & $0.1947(9)$ & $0.3426(9)$ \\
\hline $\mathrm{C}(2 \mathrm{~B})$ & $0.1864(15)$ & $0.3243(13)$ & $0.4351(12)$ \\
\hline$C(3 B)$ & $0.3151(13)$ & $0.3507(9)$ & $0.3419(9)$ \\
\hline$C(4 B)$ & $0.2748(13)$ & $0.0420(8)$ & $0.4348(9)$ \\
\hline$C(5 B)$ & $0.3470(13)$ & $0.0733(13)$ & $0.5705(13)$ \\
\hline $\mathrm{C}(6 \mathrm{~B})$ & $0.1791(13)$ & $0.1441(11)$ & $0.5112(12)$ \\
\hline$C(7 B)$ & $0.4126(13)$ & $0.0952(12)$ & $0.3498(13)$ \\
\hline$C(8 B)$ & $0.5350(16)$ & $0.1208(13)$ & $0.4681(10)$ \\
\hline $\mathrm{C}(9 \mathrm{~B})$ & $0.5125(16)$ & $0.2265(15)$ & $0.3486(13)$ \\
\hline $\mathrm{C}(10 \mathrm{~B})$ & $0.5379(10)$ & $0.3460(11)$ & $0.5429(8)$ \\
\hline$C(11 B)$ & $0.5069(15)$ & $0.3856(15)$ & $0.4018(13)$ \\
\hline $\mathrm{C}(12 \mathrm{~B})$ & $0.3797(16)$ & $0.4372(12)$ & $0.4887(11)$ \\
\hline$C(13 B)$ & $0.3816(12)$ & $0.2328(10)$ & $0.4942(11)$ \\
\hline$C(14 B)$ & $0.2542(9)$ & $0.2381(6)$ & $0.6510(8)$ \\
\hline$C(15 B)$ & $0.3434(9)$ & $0.2494(6)$ & $0.6732(8)$ \\
\hline$C(16 B)$ & $0.3822(9)$ & $0.3242(6)$ & $0.6653(8)$ \\
\hline$C(17 B)$ & $0.3318(9)$ & $0.3877(6)$ & $0.6352(8)$ \\
\hline$C(18 B)$ & $0.2426(9)$ & $0.3764(6)$ & $0.6130(8)$ \\
\hline C(19B) & $0.2038(9)$ & $0.3016(6)$ & $0.6209(8)$ \\
\hline
\end{tabular}

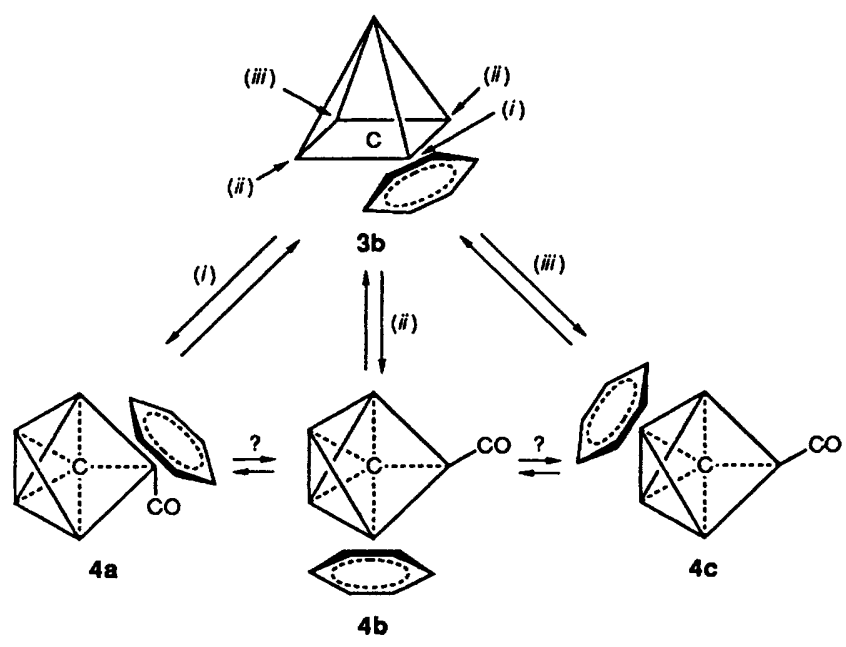

Scheme 2

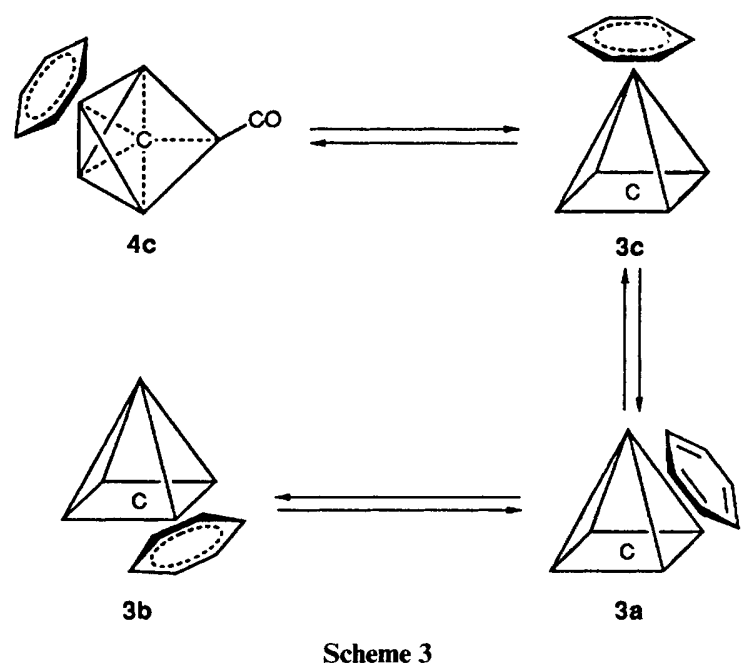

ligands. An alternative mechanism, in which the isomer interconversion is brought about by a mechanism related to that postulated for the reaction with $\mathrm{CO}$, cannot be ruled out. In this alternative the initial step may be envisaged as involving solvent addition to a ruthenium atom via any of the three steps described above. However, the likelihood that this reaction would occur in hexane must be remote and it is more likely that some decomposition occurs to produce $\mathrm{CO}$ which reacts to bring about this isomerization according to the suggested route. 
Table 10 Fractional atomic coordinates for compound 4a

\begin{tabular}{lrll} 
Atom & \multicolumn{1}{c}{$x$} & $y$ & \multicolumn{1}{l}{} \\
$\mathrm{Ru}(1)$ & $0.17815(12)$ & $0.24260(8)$ & $0.32388(8)$ \\
$\mathrm{Ru}(2)$ & $-0.15502(12)$ & $0.16648(8)$ & $0.41424(8)$ \\
$\mathrm{Ru}(3)$ & $-0.03095(13)$ & $0.12436(8)$ & $0.26920(8)$ \\
$\mathrm{Ru}(4)$ & $-0.05633(12)$ & $0.30417(8)$ & $0.23855(8)$ \\
$\mathrm{Ru}(5)$ & $-0.01890(12)$ & $0.32727(8)$ & $0.41242(8)$ \\
$\mathrm{O}(1)$ & $0.3420(11)$ & $0.1113(7)$ & $0.4299(7)$ \\
$\mathrm{O}(2)$ & $0.3286(15)$ & $0.2185(13)$ & $0.1761(9)$ \\
$\mathrm{O}(3)$ & $0.3697(14)$ & $0.3884(9)$ & $0.3735(12)$ \\
$\mathrm{O}(4)$ & $0.0891(12)$ & $0.0994(8)$ & $0.5201(7)$ \\
$\mathrm{O}(5)$ & $0.1002(12)$ & $-0.0340(8)$ & $0.3488(7)$ \\
$\mathrm{O}(6)$ & $-0.2940(14)$ & $0.0460(8)$ & $0.1845(9)$ \\
$\mathrm{O}(7)$ & $0.1003(16)$ & $0.0923(9)$ & $0.1135(9)$ \\
$\mathrm{O}(8)$ & $-0.0848(13)$ & $0.2495(9)$ & $0.0620(7)$ \\
$\mathrm{O}(9)$ & $-0.3535(12)$ & $0.3604(8)$ & $0.2297(8)$ \\
$\mathrm{O}(10)$ & $0.0950(14)$ & $0.4681(8)$ & $0.2057(10)$ \\
$\mathrm{O}(11)$ & $-0.2759(14)$ & $0.4243(8)$ & $0.4421(8)$ \\
$\mathrm{O}(12)$ & $0.1124(14)$ & $0.4990(9)$ & $0.3952(10)$ \\
$\mathrm{O}(13)$ & $0.0983(15)$ & $0.3013(10)$ & $0.5896(8)$ \\
$\mathrm{C}(1)$ & $0.2766(15)$ & $0.1632(10)$ & $0.3937(10)$ \\
$\mathrm{C}(2)$ & $0.2745(19)$ & $0.2250(14)$ & $0.2343(13)$ \\
$\mathrm{C}(3)$ & $0.2914(17)$ & $0.3335(11)$ & $0.3538(13)$ \\
$\mathrm{C}(4)$ & $-0.0043(17)$ & $0.1233(11)$ & $0.4770(10)$ \\
$\mathrm{C}(5)$ & $0.0047(13)$ & $0.0242(10)$ & $0.3206(10)$ \\
$\mathrm{C}(6)$ & $-0.1961(18)$ & $0.0760(10)$ & $0.2195(11)$ \\
$\mathrm{C}(7)$ & $0.0606(19)$ & $0.1076(11)$ & $0.1746(12)$ \\
$\mathrm{C}(8)$ & $-0.0697(17)$ & $0.2717(11)$ & $0.1274(10)$ \\
$\mathrm{C}(9)$ & $-0.2455(16)$ & $0.3351(10)$ & $0.2325(9)$ \\
$\mathrm{C}(10)$ & $0.0384(19)$ & $0.4077(13)$ & $0.2167(13)$ \\
$\mathrm{C}(11)$ & $-0.1809(18)$ & $0.3847(12)$ & $0.4315(11)$ \\
$\mathrm{C}(12)$ & $0.0661(20)$ & $0.4312(12)$ & $0.3987(12)$ \\
$\mathrm{C}(13)$ & $0.0568(15)$ & $0.3126(12)$ & $0.5219(12)$ \\
$\mathrm{C}(14)$ & $-0.0302(13)$ & $0.2268(9)$ & $0.3386(9)$ \\
$\mathrm{C}(15)$ & $-0.3743(10)$ & $0.1566(7)$ & $0.3448(5)$ \\
$\mathrm{C}(16)$ & $-0.3357(10)$ & $0.0781(7)$ & $0.3797(5)$ \\
$\mathrm{C}(17)$ & $-0.2946(10)$ & $0.0723(7)$ & $0.4635(5)$ \\
$\mathrm{C}(18)$ & $-0.2921(10)$ & $0.1450(7)$ & $0.5124(5)$ \\
$\mathrm{C}(19)$ & $-0.3307(10)$ & $0.2234(7)$ & $0.4775(5)$ \\
$\mathrm{C}(20)$ & $-0.3718(10)$ & $0.2292(7)$ & $0.3937(5)$
\end{tabular}

\section{Experimental}

Synthesis and Characterization.-All syntheses were performed with the exclusion of air using solvents dried by conventional procedures. Product separation was achieved by thin-layer chromatography using plates supplied by Merck pre-coated with a $0.25 \mathrm{~mm}$ layer of Kieselgel $60 \mathrm{~F}_{254}$. Eluents were mixed from standard laboratory-grade solvents. Infrared spectra were recorded in $\mathrm{CH}_{2} \mathrm{Cl}_{2}$ using $\mathrm{NaCl}$ cells $(0.5 \mathrm{~mm}$ path length) on a Perkin Elmer 1710 Fourier-transform spectrometer using carbon monoxide gas as calibrant. Mass spectra were obtained by electron-impact ionisation on a Kratos-AEI-MS12 instrument, using bis(perfluoroheptyl)-s-triazene as calibrant. Proton NMR spectra were recorded using a Bruker WM250 spectrometer using an internal deuterium lock.

The $\left[\mathrm{Ru}_{5} \mathrm{C}(\mathrm{CO})_{15}\right]$ cluster was prepared according to the literature method. ${ }^{13}$ Trimethylamine $N$-oxide was sublimed immediately prior to use and cyclohexa-1,3-diene was used as received (Aldrich).

Reaction of $\left[\mathrm{Ru}_{5} \mathrm{C}(\mathrm{CO})_{15}\right]$ 1. An excess of cyclohexa-1,3diene $\left(0.5 \mathrm{~cm}^{3}\right)$ was added to a solution of $\left[\mathrm{Ru} \mathrm{u}_{5} \mathrm{C}(\mathrm{CO})_{15}\right] 1$ (100 mg) in $\mathrm{CH}_{2} \mathrm{Cl}_{2}\left(70 \mathrm{~cm}^{3}\right)$. A solution of $\mathrm{Me}_{3} \mathrm{NO}(16 \mathrm{mg}$, 2 mol equivalents) in $\mathrm{CH}_{2} \mathrm{Cl}_{2}\left(10 \mathrm{~cm}^{3}\right)$ was added dropwise over a period of $5 \mathrm{~min}$. The mixture was stirred for $30 \mathrm{~min}$ at room temperature and the reaction monitored by IR spectroscopy until complete conversion of the starting material was ensured. The solvent was removed in vacuo and the residue separated by TLC using dichloromethane-ethyl acetate-hexane $(2: 1: 17 \mathrm{v} / \mathrm{v})$ as eluent. The red band was extracted as the major product and characterized as $\left[\mathrm{Ru}_{5} \mathrm{C}(\mathrm{CO})_{13}\left(\mu-\eta^{2}: \eta^{2}-\mathrm{C}_{6} \mathrm{H}_{8}\right)\right] 2(32 \mathrm{mg})$ by spectroscopy.
Reaction of $\left[\mathrm{Ru}_{5} \mathrm{C}(\mathrm{CO})_{13}\left(\mu-\eta^{2}: \eta^{2}-\mathrm{C}_{6} \mathrm{H}_{8}\right)\right]$ 2. Trimethylamine $N$-oxide ( $3 \mathrm{mg}, 1.1$ mol equivalent) in $\mathrm{CH}_{2} \mathrm{Cl}_{2}\left(5 \mathrm{~cm}^{3}\right)$ was added dropwise over a period of $5 \mathrm{~min}$ to a solution of $\left[\mathrm{Ru}{ }_{5} \mathrm{C}(\mathrm{CO})_{13}\left(\mu-\eta^{2}: \eta^{2}-\mathrm{C}_{6} \mathrm{H}_{8}\right)\right] 2(32 \mathrm{mg})$ in $\mathrm{CH}_{2} \mathrm{Cl}_{2}\left(50 \mathrm{~cm}^{3}\right)$. The mixture was stirred for $15 \mathrm{~min}$ at room temperature and the reaction monitored by IR spectroscopy, until complete conversion of the starting material was observed. The solvent was removed under a stream of nitrogen and the products extracted by TLC using dichloromethane-ethyl acetate-hexane $(2: 1: 17 \mathrm{v} / \mathrm{v})$ as eluent. The red and black bands were extracted and spectroscopically characterized as $\left[\mathrm{Ru}_{5} \mathrm{C}(\mathrm{CO})_{12}\left(\mu_{3^{-}}\right.\right.$ $\left.\left.\eta^{2}: \eta^{2}: \eta^{2}-\mathrm{C}_{6} \mathrm{H}_{6}\right)\right] 3 \mathrm{a}(14 \mathrm{mg})$ and $\left[\mathrm{Ru}_{5} \mathrm{C}(\mathrm{CO})_{12}\left(\eta^{6}-\mathrm{C}_{6} \mathrm{H}_{6}\right)\right]$ 3b, respectively.

Thermolysis of compound 2. Compound 2 (24 mg) was dissolved in hexane $\left(80 \mathrm{~cm}^{3}\right)$ and heated under reflux for $18 \mathrm{~h}$ during which time the solution changed from red to black. Infrared spectroscopy used to monitor the thermolysis indicated that no starting material remained. The solvent was removed in vacuo and the residue separated by TLC using $\mathrm{CH}_{2} \mathrm{Cl}_{2}$-hexane $(3: 7 \mathrm{v} / \mathrm{v})$ as eluent. The black band was extracted as the major product and characterized as $\left[\mathrm{Ru}_{5} \mathrm{C}\right.$ $\left.(\mathrm{CO})_{12}\left(\eta^{6}-\mathrm{C}_{6} \mathrm{H}_{6}\right)\right] 3 \mathrm{~b}(20 \mathrm{mg})$ by IR spectroscopy.

Thermolysis of $\left[\mathrm{Ru}_{5} \mathrm{C}(\mathrm{CO})_{12}\left(\mu_{3}-\eta^{2}: \eta^{2}: \eta^{2}-\mathrm{C}_{6} \mathrm{H}_{6}\right)\right] 3 \mathrm{a}$. Compound $3 \mathrm{a}(10 \mathrm{mg})$ was heated under reflux in hexane $\left(30 \mathrm{~cm}^{3}\right)$ for $4 \mathrm{~h}$. During this time the colour changed from red to black and the IR spectrum indicated complete conversion of the starting material to $\left[\mathrm{Ru}_{5} \mathrm{C}(\mathrm{CO})_{12}\left(\eta^{6}-\mathrm{C}_{6} \mathrm{H}_{6}\right)\right]$ 3b. This was confirmed by spot TLC which showed no other products present.

Preparation of $\left[\mathrm{Ru}_{5} \mathrm{C}(\mathrm{CO})_{12}\left(\mathrm{C}_{6} \mathrm{H}_{6}\right)\right]$ 3c. Crystals of $\left[\mathrm{Ru}_{5} \mathrm{C}(\mathrm{CO})_{13}\left(\eta^{6}-\mathrm{C}_{6} \mathrm{H}_{6}\right)\right] \mathbf{4 a}(10 \mathrm{mg})$ were dissolved in $\mathrm{CH}_{2} \mathrm{Cl}_{2}$ $\left(30 \mathrm{~cm}^{3}\right)$ and on standing under a nitrogen atmosphere for $30 \mathrm{~min}$ the colour changed from yellow to black. Infrared spectroscopy showed that no starting material remained and spot TLC demonstrated only one product had formed which was characterized by mass spectroscopy as $\left[\mathrm{Ru}_{5} \mathrm{C}(\mathrm{CO})_{12^{-}}\right.$ $\left.\left(\eta^{6}-\mathrm{C}_{6} \mathrm{H}_{6}\right)\right] 3 \mathrm{c}$.

Reaction of compound $3 \mathrm{c}$ with $\mathrm{CO}$. A steady stream of $\mathrm{CO}$ was bubbled through a solution of $\left[\mathrm{Ru}_{5} \mathrm{C}(\mathrm{CO})_{12}\left(\mathrm{C}_{6} \mathrm{H}_{6}\right)\right] 3 \mathrm{e}(20$ $\mathrm{mg})$ in $\mathrm{CH}_{2} \mathrm{Cl}_{2}\left(30 \mathrm{~cm}^{3}\right)$. After $5 \mathrm{~min}$ the solution had changed from black to yellow. Complete consumption of the starting material was indicated by IR spectroscopy. The reaction vessel was sealed and stored at $-20^{\circ} \mathrm{C}$ for $5 \mathrm{~d}$ during which time yellow crystals of $\left[\mathrm{Ru}_{5} \mathrm{C}(\mathrm{CO})_{13}\left(\eta^{6}-\mathrm{C}_{6} \mathrm{H}_{6}\right)\right]$ 4a were obtained. Spot TLC indicated that the reaction was quantitative.

Thermolysis of compound 3c. Compound $3 \mathbf{c}(8 \mathrm{mg})$ was refluxed in hexane $\left(25 \mathrm{~cm}^{3}\right)$ for $40 \mathrm{~h}$. Infrared spectroscopy indicated complete conversion to $\left[\mathrm{Ru} \mathrm{u}_{5} \mathrm{C}(\mathrm{CO})_{12}\left(\eta^{6}-\mathrm{C}_{6} \mathrm{H}_{6}\right)\right]$ 3b $(8 \mathrm{mg})$. This was confirmed by spot TLC which showed that no other products were present.

$X$-Ray Structure Determination.-The diffraction data for all species discussed herein were collected on an Enraf-Nonius CAD-4 diffractometer equipped with a graphite monochromator (Mo-K $\alpha$ radiation, $\lambda=0.71069 \AA$ ). Diffraction intensities were collected in the $\omega-2 \theta$ scan mode at room temperature for compounds 3a, 3b and $\mathbf{4 a}$, while data for compound $\mathbf{2}$ were measured at $200 \mathrm{~K}$. Crystal data and measurement details are summarized in Table 6 . The structures were solved by means of direct methods followed by Fourier difference syntheses and subsequent least-squares refinement. Scattering factors for neutral atoms were taken from ref. 17(a) and the SHELX 76 program ${ }^{17 b}$ was used for all calculations. Absorption corrections for 3a, 3b and 4a were applied using the Walker and Stuart method ${ }^{17 c}$ once complete structural models were available and all atoms refined isotropically. All non-H atoms were treated anisotropically for $3 a$ and $4 a$, while in $3 b$ the benzene groups were refined isotropically. Two independent molecules are present in the asymmetric unit of $3 \mathbf{b}$ : structural parameters discussed in the text are given as pairs of chemically corresponding values in the two molecules. A fraction of $\mathrm{CH}_{2} \mathrm{Cl}_{2}$ solvent molecule was found 
in the lattice of compound 2 , the site occupation factor for the two chlorine and the carbon atoms converged to $c a .0 .25$. The benzene $\mathbf{H}$ atoms in compounds $2,3 \mathrm{~b}$ and $\mathbf{4 a}$ were added in calculated positions and refined 'riding' on their respective $\mathrm{C}$ atoms; those in 3a were found in the final Fourier difference maps and refined with $\mathrm{C}-\mathrm{H}$ bond length constraints. Common isotropic thermal parameters were refined for the benzene $\mathrm{H}$ atoms in compounds $3 \mathrm{~b}$ and $4 \mathrm{a}\left[0.10(2)\right.$ and $0.10(3) \AA^{2}$, respectively]. Fractional atomic coordinates are reported in Tables 7-10 for compounds 2, 3a, 3b and 4a, respectively.

Additional material available from the Cambridge Crystallographic Data Centre comprises $\mathbf{H}$-atom coordinates, thermal parameters and remaining bond lengths and angles.

\section{Acknowledgements}

We thank the SERC, British Petroleum (P. J. D.) and the Ministero dell' Universita' e della Ricerca Scientifica e Tecnologica (Italy) for financial support. D. B., F. G. and B. F. G. J. acknowledge NATO for a travel grant.

\section{References}

1 D. Braga, F. Grepioni, B. F. G. Johnson, J. Lewis, C. E. Housecroft and M. Martinelli, Organometallics, 1991, 10, 1260.

2 M. A. Gallop, B. F. G. Johnson, J. Lewis and P. R. Raithby, J. Chem. Soc., Chem. Commun., 1987, 1809.

3 (a) D. Braga, F. Grepioni, B. F. G. Johnson, J. Lewis, M. Martinelli and M. A. Gallop, J. Chem. Soc., Chem. Commun., 1990, 53; (b) D. Braga, F. Grepioni, B. F. G. Johnson, E. Parisini,
M. Martinelli, M. A. Gallop and J. Lewis, J. Chem. Soc., Dalton Trans., 1992, 807 .

4 H. Chen, B. F. G. Johnson, J. Lewis, D. Braga, F. Grepioni and E. Parisini, J. Chem. Soc., Dalton Trans., 1991, 215.

5 D. Braga, F. Grepioni, B. F. G. Johnson, H. Chen and J. Lewis, J. Chem. Soc., Dalton Trans., 1991, 2559.

6 B. F. G. Johnson, R. D. Johnston and J. Lewis, Chem. Commun., 1967, 1057; J. Chem. Soc. A, 1968, 2865.

7 R. Mason and W. R. Robinson, Chem. Commun., 1968, 468.

8 M. P. Gomez-Sal, B. F. G. Johnson, J. Lewis, P. R. Raithby and A. H. Wright, J. Chem. Soc., Chem. Commun., 1985, 1682.

9 M. A. Van Hove, R. F. Lin and G. A. Somorjai, J. Am. Chem. Soc., $1986,108,2532$

10 F. P. Netzer, H. H. Green, H. Kuhlenbeck and M. Neumann, Chem. Phys. Lett., 1987, 133, 49.

11 D. Braga, Chem. Rev., 1992, 92, 633.

12 D. Braga, F. Grepioni and P. Sabatino, J. Chem. Soc., Dalton Trans. 1990, 3137; D. Braga and F. Grepioni, Organometallics, 1991, 10, 1254, 2563; 1992, 11, 711 .

13 B. F. G. Johnson, J. Lewis, J. N. Nicholls, J. Puga, P. R. Raithby, M. J. Rosales, M. McPartlin and W. Clegg, J. Chem. Soc., Dalton Trans., 1983, 277.

14 H. Wadepohl, Angew. Chem., Int. Ed. Engl., 1992, 31, 247.

15 P. J. Bailey, D. Braga, P. J. Dyson, F. Grepioni, B. F. G. Johnson, J. Lewis and P. Sabatino, J. Chem. Soc., Chem. Commun., 1992, 177.

16 H. Wadepohl, K. Buchner and H. Pritzkow, Angew. Chem., Int. Ed. Engl., 1987, 26, 1259.

17 (a) International Tables for X-Ray Crystallography, Kynoch Press, Birmingham, 1979, vol. 4, pp. 99-149; (b) G. M. Sheldrick, SHELX 76, Program for Crystal Structure Determination, University of Cambridge, 1976; (c) N. Walker and D. Stuart, Acta Crystallogr., Sect. B, 1983, 39, 158

Received 14th July 1992; Paper 2/03732G 